\title{
A Brief Review of Plasma Enhanced Atomic Layer Deposition of $\mathrm{Si}_{3} \mathrm{~N}_{4}$
}

\author{
Received June 4, 2019; revised July 22, 2019; accepted August 5, 2019
}

\author{
You Jin Jia, Ki Seok Kimª, Ki Hyun Kimª , Ji Young Byun ${ }^{a}$, and Geun Young Yeom ${ }^{\mathrm{a}, \mathrm{b}, *}$ \\ aschool of Advanced Materials Science and Engineering, Sungkyunkwan University, Suwon 16419, Republic of Korea \\ ${ }^{b}$ SKKU Advanced Institute of Nano Technology (SAINT), Sungkyunkwan University, Suwon 16419, Republic of Korea
}

*Corresponding author E-mail: gyyeom@skku.edu

\begin{abstract}
Silicon nitride $\left(\mathrm{SiN}_{\mathrm{x}}\right)$ thin films have attracted interest as an important material for use in next-generation devices such as a gate spacer in 3D fin field-effect transistors (finFETs), charge trap layers, etc. Many studies using the $\mathrm{SiN}_{\mathrm{x}}$ plasma enhanced atomic layer deposition (PEALD) method have been conducted, owing to its advantages over other $\mathrm{SiN}_{\mathrm{x}}$ deposition methods. In this review, the recent studies on PEALD of SiN $\mathrm{x}_{\mathrm{x}}$ thin films are summarized, and the effects of some process parameters including plasma power, frequency, and process temperature on the material properties of $\mathrm{SiN}_{\mathrm{x}}$ are discussed. In addition, some properties of $\mathrm{SiN}_{\mathrm{x}}$ thin films such as conformality, wet etch rate, and others are reviewed.
\end{abstract}

Keywords: Silicon nitride $\left(\mathrm{Si}_{3} \mathrm{~N}_{4}\right)$, Plasma enhanced atomic layer deposition (PEALD), Process temperature, Step coverage, Wet etch rate

\section{Introduction}

Recently, silicon nitride $\left(\mathrm{SiN}_{\mathrm{x}}\right)$ has attracted considerable interest owing to its diverse range of applications [1-10]. For instance, $\mathrm{SiN}_{\mathrm{x}}$ is used as a permeation barrier for flexible organic light emitting devices [7-10] or as a charge trap layer for logic and memory devices [4]; $\mathrm{SiN}_{\mathrm{x}}$ gate spacers have also been studied extensively $[1-3,6]$. High quality and excellent conformality are critical requirements for various applications of $\mathrm{SiN}_{\mathrm{x}}$ thin films. In addition, lowering the deposition temperature is an important factor for devices employing low temperature substrates such as polymer substrates. To satisfy such a requirement for employing $\mathrm{SiN}_{\mathrm{x}}$ thin films, many studies have used various deposition techniques such as chemical vapor deposition (CVD), low pressure chemical vapor deposition (LPCVD), plasma enhanced chemical vapor deposition (PECVD), atomic layer deposition (ALD), plasma enhanced atomic layer deposition (PEALD), and so on $[11-43]$.

Low pressure chemical vapor deposition is the most common technique used to fabricate $\mathrm{SiN}_{\mathrm{x}}$ thin films because of its simple method and low cost. However, it is difficult to achieve a conformal layer on a high aspect ratio structure. In addition, the deposition needs to be conducted at high temperature $\left(>700{ }^{\circ} \mathrm{C}\right)[17,18]$. Plasma enhanced chemical vapor deposition can deposit films at temperatures lower than that by using thermal LPCVD. Unfortunately, this leads to poor step coverage and low film quality $[3,15,16]$. To address issues related to conformality, the ALD technique has been studied extensively [19-26]; ALD is a cyclic process that offers atomic scale thickness control of the material that is being deposited. In addition, ALD methods can deposit thin films with high quality in terms of low wet etch rate and high conformality at low process temperatures $[25,26]$. However, ALD methods have several challenges such as a relatively high thermal budget for actual device application and low throughput (GPC > $2 \AA / \mathrm{min}$ ) that hinders the industrialization of ALD methods $[22,26]$. By assisting with a plasma for dissociating reactive gases during ALD with PEALD processes, a thin film with a good step coverage on a high aspect ratio structure can be deposited at low temperatures. A plasma with reactant molecules can be used instead of exposure to reactant molecules only during the reactant exposure step; highly reactive species are formed during the reactant exposure step, which allows the deposition of high quality films with a high growth rate while lowering deposition temperatures [15,27-42].

In this paper, we briefly reviewed the recent work of PEALD $\mathrm{SiN}_{\mathrm{x}}$ and related process parameters that could determine film characteristics. Furthermore, this review will discuss properties of the film that are dependent on deposition conditions. A schematic of a PEALD cycle is shown in Fig. 1. Each $\mathrm{SiN}_{\mathrm{x}}$ PEALD cycle can be divided into four steps. In the first precursor adsorption step, similar to ALD, a Si precursor is introduced into the deposition chamber. Si precursors are chemisorbed on the surface through self-limiting reactions followed by a purge step. In the following plasma exposure step (for ALD, reactant exposure step), plasma-generated reactive species react with the adsorbed precursor on the surface. As a plasma source, capacitively coupled plasma (CCP) or inductively coupled plasma (ICP) sources are commonly used along with $\mathrm{N}_{2}, \mathrm{NH}_{3}$, or $\mathrm{N}_{2} / \mathrm{H}_{2}$ to generate reactive plasmas $[5,15,27-40]$. To optimize PEALD processes, various parameters should be adjusted to meet the material properties of $\mathrm{SiN}_{\mathrm{x}}$ required for the application.

\section{Process parameters}

As mentioned above, in PEALD, there are various process parameters including reactant gas, plasma source, precursor, precursor 


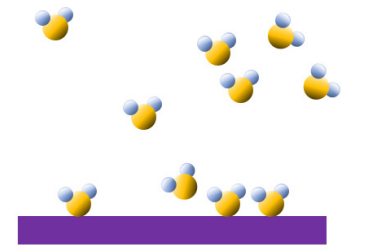

Precursor adsorption
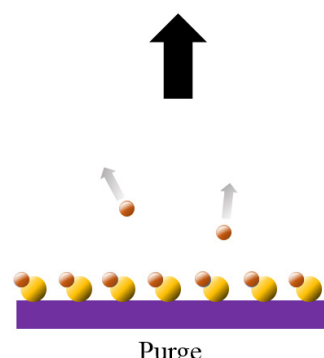

Purge
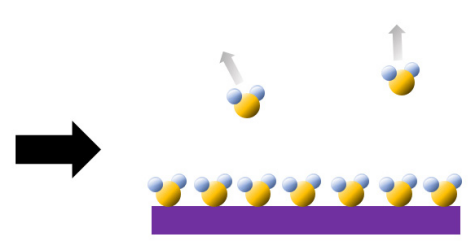

Purge

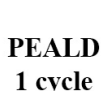

1 cycle
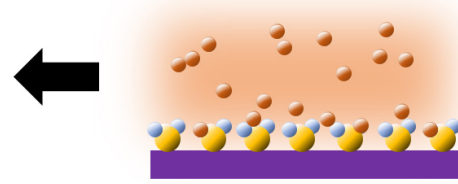

Plasma exposure dose time, purge time, process temperature, and others. In this section, the effects of some process parameters influencing $\mathrm{SiN}_{\mathrm{x}}$ deposition are briefly discussed.

\section{1) Precursors}

Many kinds of precursors such as trisilylamine (TSA), diisopropylaminosilane (DIPAS), bis(tertiary-butyl-amino)silane (BTBAS), trisdimethylaminosilane (3DMAS), di(sec-butylamino)silane (DSBAS), hexachlorodisilane (HCDS), pentachlorodisilane (PCDS), dichlorosilane (DCS), and tetramethylsilane (TMS) have been reported as $\mathrm{Si}$ sources of $\mathrm{SiN}_{\mathrm{x}}$ PEALD [5,27-30,32-36,38-40]. Table I summarizes studies on $\mathrm{SiN}_{\mathrm{x}}$ PEALD in recent decades; it also provides details on Si precursors, reactant gas, plasma source, deposition temperature, and growth rate.

\section{2) Plasma conditions}

Plasma characteristics such as density of radicals, energy, and density of electrons and ions have a considerable influence on $\mathrm{SiN}_{\mathrm{x}}$ PEALD processes. Therefore, controlling plasma conditions such as rf

Figure 1. (Color online) Schematic of a PEALD cycle.

Table I. Summary of recent studies on PEALD $\operatorname{SiN}_{x}$.

\begin{tabular}{|c|c|c|c|c|c|}
\hline Si precursor & Reactant & $\begin{array}{l}\text { Plasma source / } \\
\text { Frequency }\end{array}$ & $\begin{array}{l}\text { Process } \\
\text { temperature }\end{array}$ & GPC $(\AA ̊ / c y c l e)$ & Ref. \\
\hline Silane $\left(\mathrm{SiH}_{4}\right)$ & $\mathrm{N}_{2}$ & $\begin{array}{c}\mathrm{CCP} \\
200-400 \mathrm{kHz}\end{array}$ & $250-400{ }^{\circ} \mathrm{C}$ & $0.25-2$ & 15 \\
\hline Trisilyamine (TSA, $\left.\mathrm{Si}_{3} \mathrm{H}_{9} \mathrm{~N}\right)$ & $\mathrm{NH}_{3}$ & $\begin{array}{l}\text { ICP } \\
13.56 \mathrm{MHz}\end{array}$ & $250-350{ }^{\circ} \mathrm{C}$ & 0.65 & 27 \\
\hline Hexachlorodisilane (HCDS, $\mathrm{Si}_{2} \mathrm{Cl}_{6}$ ) & $\mathrm{NH}_{3}$ & $\begin{array}{c}\text { CCP } \\
13.56 \mathrm{MHz}\end{array}$ & $350-450{ }^{\circ} \mathrm{C}$ & $1.2\left(400{ }^{\circ} \mathrm{C}\right)$ & 28 \\
\hline $\operatorname{Bis}\left(\right.$ tertiary-butylamino)silane (BTBAS, $\left.\mathrm{SiH}_{2}\left(\mathrm{NH}^{t} \mathrm{Bu}\right)_{2}\right)$ & $\mathrm{N}_{2}$ & $\begin{array}{c}\text { ICP } \\
13.56 \mathrm{MHz}\end{array}$ & $400-500{ }^{\circ} \mathrm{C}$ & $0.15\left(500{ }^{\circ} \mathrm{C}\right)$ & 29 \\
\hline Trisdimethylaminosilane (3DMAS, $\mathrm{C}_{6} \mathrm{H}_{19} \mathrm{~N}_{3} \mathrm{Si}$ ) & $\mathrm{N}_{2}$ & \multirow{3}{*}{$\begin{array}{l}\text { ICP } \\
13.56 \mathrm{MHz}\end{array}$} & \multirow{3}{*}{$350{ }^{\circ} \mathrm{C}$} & 0.12 & \multirow{3}{*}{30} \\
\hline Dichlorosilane (DCS, $\mathrm{SiH}_{2} \mathrm{Cl}_{2}$ ) & $\mathrm{NH}_{3}$ & & & 0.24 & \\
\hline Trysilylamine (TSA, $\left.\mathrm{Si}_{3} \mathrm{H}_{9} \mathrm{~N}\right)$ & $\mathrm{N}_{2}$ & & & - & \\
\hline $\mathrm{Bis}\left(\right.$ dimethylaminomethylsilyl)trimethylsilyl amine (DTDN2- $\mathrm{H} 2, \mathrm{C}_{9} \mathrm{H}_{29} \mathrm{~N}_{3} \mathrm{Si}_{3}$ ) & $\mathrm{N}_{2}$ & $27.12 \mathrm{MHz}$ & $250-400{ }^{\circ} \mathrm{C}$ & 0.36 & 31 \\
\hline Neopentasilane (NPS, $\left.\left(\mathrm{SiH}_{3}\right)_{4} \mathrm{Si}\right)$ & \multirow{2}{*}{$\mathrm{N}_{2}$} & \multirow{2}{*}{$\begin{array}{c}\text { CCP } \\
13.56 \mathrm{MHz}\end{array}$} & \multirow{2}{*}{$250-300{ }^{\circ} \mathrm{C}$} & 1.4 & \multirow{2}{*}{32} \\
\hline Trisilylamine $\left(\mathrm{TSA},\left(\mathrm{SiH}_{3}\right)_{3} \mathrm{~N}\right)$ & & & & 1.2 & \\
\hline Di(sec-butylamino)silane (DSBAS, $\left.\mathrm{SiH}_{3} \mathrm{~N}\left({ }^{{ }^{S}} \mathrm{Bu}\right)_{2}\right)$ & $\mathrm{N}_{2}$ & $\begin{array}{c}\text { ICP } \\
13.56 \mathrm{MHz}\end{array}$ & $100-500{ }^{\circ} \mathrm{C}$ & $\sim 0.19\left(100{ }^{\circ} \mathrm{C}\right)$ & 33 \\
\hline Diisopropylaminosilane (DIPAS, $\mathrm{C}_{6} \mathrm{H}_{17} \mathrm{NSi}$ ) & $\mathrm{N}_{2}$ & $\begin{array}{l}\mathrm{CCP} \\
13.56 \mathrm{MHz}\end{array}$ & $150-250{ }^{\circ} \mathrm{C}$ & $0.3\left(100{ }^{\circ} \mathrm{C}\right)$ & 34 \\
\hline \multirow{2}{*}{ Pentachlorodisilane (PCDS, $\mathrm{HSi}_{2} \mathrm{Cl}_{5}$ ) } & $\mathrm{N}_{2}$ & \multirow{2}{*}{$\begin{array}{l}\text { Hollow cathode } \\
13.56 \mathrm{MHz}\end{array}$} & \multirow{2}{*}{$270-360{ }^{\circ} \mathrm{C}$} & 0.2 & \multirow{2}{*}{35} \\
\hline & $\mathrm{N}_{2} / \mathrm{NH}_{3}$ & & & $\sim 1\left(270{ }^{\circ} \mathrm{C}\right)$ & \\
\hline \multirow{2}{*}{ Hexachlorodisilane (HCDS, $\mathrm{Si}_{2} \mathrm{Cl}_{6}$ ) } & $\mathrm{N}_{2} / \mathrm{NH}_{3}$ & \multirow{2}{*}{ Hollow cathode } & \multirow{2}{*}{$270-360{ }^{\circ} \mathrm{C}$} & $\sim 0.68$ & \multirow{2}{*}{5} \\
\hline & $\mathrm{Ar} / \mathrm{NH}_{3}$ & & & $\sim 0.57$ & \\
\hline $\begin{array}{l}\text { Two step } \\
\left.\text { Hexachlorodisilane (HCDS, } \mathrm{Si}_{2} \mathrm{Cl}_{6}\right)+ \text { Methylamine }\left(\mathrm{CH}_{3} \mathrm{NH}_{2}\right)\end{array}$ & $\mathrm{N}_{2}$ & $\begin{array}{c}\text { CCP } \\
13.56 \mathrm{MHz}\end{array}$ & $400{ }^{\circ} \mathrm{C}$ & $\sim 0.9$ & 36 \\
\hline \multirow{2}{*}{ 1,3-di-isopropylamino-2,4-dimethylcyclosilazane $\left(\mathrm{CSN}-2, \mathrm{C}_{8} \mathrm{H}_{22} \mathrm{~N}_{2} \mathrm{Si}_{2}\right)$} & $\mathrm{N}_{2}$ & \multirow{2}{*}{$27.12 \mathrm{MHz}$} & \multirow{2}{*}{$200-500{ }^{\circ} \mathrm{C}$} & 0.43 & \multirow{2}{*}{37} \\
\hline & $\mathrm{NH}_{3} / \mathrm{N}_{2}+\mathrm{N}_{2}$ & & & $\sim 0.35$ & \\
\hline \multirow{3}{*}{ Bis(tertiary-butyl-amino)silane (BTBAS, $\left.\mathrm{SiH}_{2}(\mathrm{NHtBu})_{2}\right)$} & \multirow{3}{*}{$\mathrm{N}_{2}$} & \multirow{3}{*}{$\begin{array}{l}\mathrm{ICP} \\
13.56 \mathrm{MHz}\end{array}$} & $85^{\circ} \mathrm{C}$ & 0.8 & \multirow{3}{*}{38} \\
\hline & & & $155^{\circ} \mathrm{C}$ & 0.3 & \\
\hline & & & $275^{\circ} \mathrm{C}$ & 0.2 & \\
\hline \multirow{4}{*}{ Bis(tertiary-butyl-amino)silane (BTBAS, $\left.\mathrm{SiH}_{2}\left(\mathrm{NH}^{\mathrm{t}} \mathrm{Bu}\right)_{2}\right)$} & \multirow{4}{*}{$\mathrm{N}_{2}$} & \multirow{4}{*}{$\begin{array}{l}\text { ICP } \\
13.56 \mathrm{MHz}\end{array}$} & $80^{\circ} \mathrm{C}$ & 0.44 & \multirow{4}{*}{39} \\
\hline & & & $120{ }^{\circ} \mathrm{C}$ & 0.33 & \\
\hline & & & $160^{\circ} \mathrm{C}$ & 0.26 & \\
\hline & & & $200{ }^{\circ} \mathrm{C}$ & 0.24 & \\
\hline Dichlorosilane (DCS, $\mathrm{SiH}_{2} \mathrm{Cl}_{2}$ ) & $\mathrm{NH}_{3}$ & $13.56 \mathrm{MHz}$ & $400-630^{\circ} \mathrm{C}$ & $1.39\left(550^{\circ} \mathrm{C}\right)$ & 40 \\
\hline
\end{tabular}




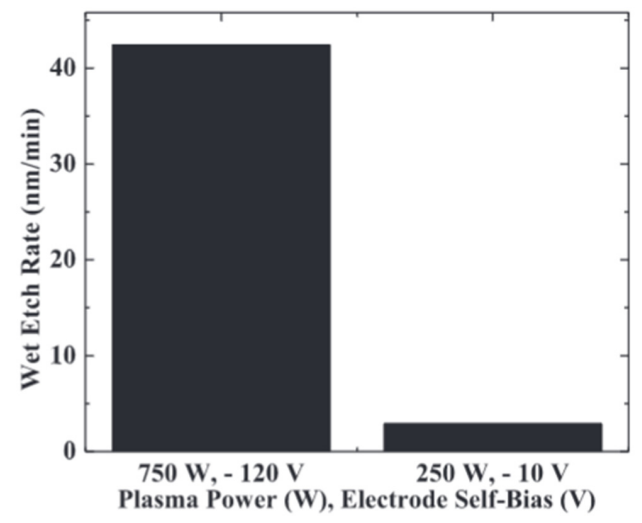

Figure 2. Wet etch rate of $\mathrm{SiN}_{\mathrm{x}}$ deposited using NPS and $\mathrm{N}_{2}$ plasma with different plasma conditions. Reproduced with permission from [32], Copyright, American Institute of Physics.

Table II. Hydrogen concentration and film density of $\mathrm{SiN}_{\mathrm{x}}$ for different plasma power. Reproduced with permission from [32], Copyright, American Institute of Physics.

\begin{tabular}{ccc}
\hline Power $(\mathrm{W})$ & $\mathrm{H}($ at. $\%)$ & Density $(\mathrm{g} / \mathrm{cc})$ \\
\hline 750 & 23.5 & 1.86 \\
250 & 11 & 2.21 \\
\hline
\end{tabular}

power and frequency is important.

Weeks et al. [32] reported PEALD $\mathrm{SiN}_{\mathrm{x}}$ using a precursor of neopentasilane (NPS) and $\mathrm{N}_{2}$ plasma by using a CCP source at the temperature of $275{ }^{\circ} \mathrm{C}$. They determined the effects of plasma power on the wet etch rate, hydrogen concentration, and film density. A high plasma power resulted in more energetic ions that could damage the depositing film. Therefore, as shown in Fig. 2, the wet etch rate of the $\mathrm{SiN}_{\mathrm{x}}$ films in a 100:1 HF solution (HF: deionized water = 1:100) decreased when the plasma power decreased from 750 to $250 \mathrm{~W}$, which was consistent with the results of low hydrogen contents and high film density, as summarized in Table II. With a decrease in the power from 750 to $250 \mathrm{~W}$, the $\mathrm{H}$ concentration decreased while the film density increased. The wet etch rate is closely related to the $\mathrm{H}$ concentration in the film and film density [30].

Park et al. [31] also investigated the effect of RF power on film property. Charge trap density, wet etch rate, N/Si ratio, carbon concentration, and oxygen concentration were measured for $\mathrm{SiN}_{\mathrm{x}}$ film deposited by PEALD using DTDN2-H2 and $\mathrm{N}_{2}$ plasma with various plasma powers ranging from 75 to $400 \mathrm{~W}$. As shown in Fig. 3, the carbon and oxygen concentrations of the film increased with increasing RF power; however, the N/Si ratio decreased. This can be attributed to the dissociation of precursor ligands that desorbed from the surface because of the high RF power of the plasma. Owing to the deposition of the carbon impurity, the wet etch rate of the film was also increased with increasing RF power.

Another important parameter influencing plasma properties such as electron density and electron temperature is the frequency of plasma generation. Thus, the plasma generation frequency also needs to be controlled to improve $\mathrm{SiN}_{\mathrm{x}}$ thin film quality. King et al. compared the Fourier-transform infrared spectroscopy (FTIR) results for $\mathrm{SiN}_{\mathrm{x}}$ deposited using $\mathrm{SiN}_{4}$ and $\mathrm{N}_{2}$ plasma with different source frequencies [15]. As shown in Fig. 4, PEALD $\mathrm{SiN}_{\mathrm{x}}$ film using a frequency of $13.56 \mathrm{MHz}$ showed a high intensity of the Si-N stretching mode. In
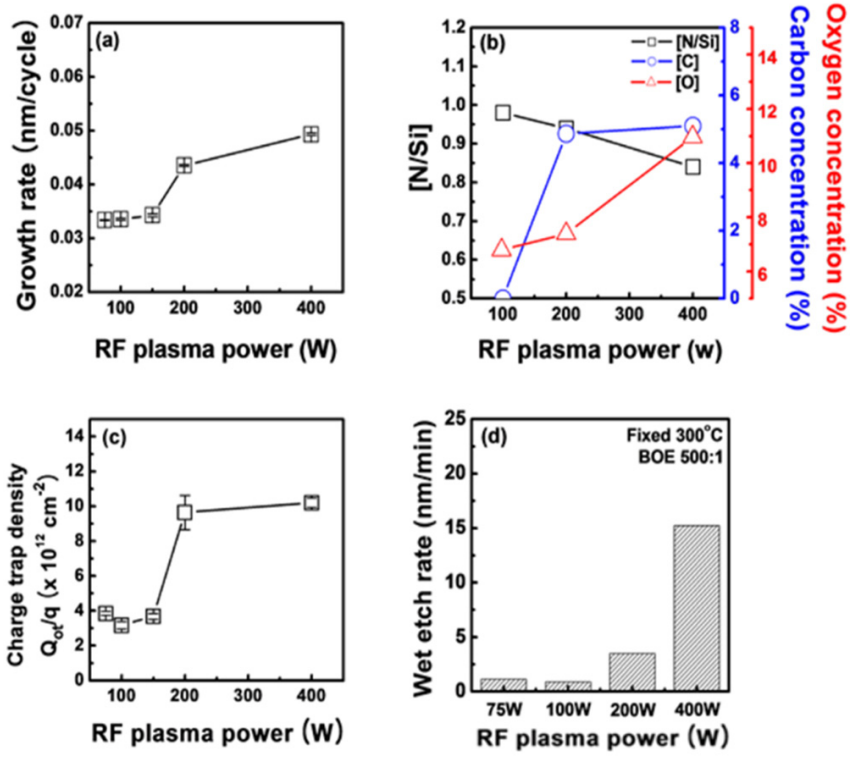

Figure 3. (Color online) (a) Growth rate per cycle (GPC), (b) carbon and oxygen concentrations and N/Si ratio, (c) charge trap density, and (d) wet etch rate with increasing RF power in the PEALD process. PEALD SiN ${ }_{x}$ films were deposited with different if plasma power. Reproduced with permission from [31], Copyright 26, American Chemical Society.

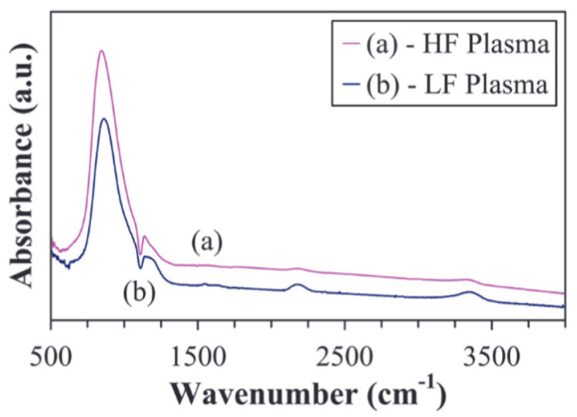

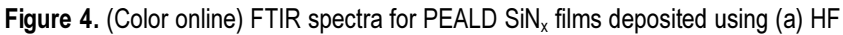
$(13.56 \mathrm{MHz}) \mathrm{N}_{2}$ plasmas and (b) LF $(200-400 \mathrm{kHz}) \mathrm{N}_{2}$ plasmas. Reproduced with permission from [15], Copyright, American Institute of Physics.

contrast, the peak intensities of the $\mathrm{Si}-\mathrm{H}$ and $\mathrm{N}-\mathrm{H}$ stretching modes were lower than those obtained from films deposited using a frequency of $200-400 \mathrm{kHz}$. A higher plasma frequency can achieve the effective decomposition of $\mathrm{N}_{2}$ gas, thus allowing a higher density of $\mathrm{N}$ and $\mathrm{N}^{+}$ions. Reactive species such as $\mathrm{N}$ and $\mathrm{N}^{+}$ions can react with the $\mathrm{Si}-\mathrm{H}$ surface bonds and form a bond with $\mathrm{Si}$ by replacing the $\mathrm{H}$ atom. Therefore, PEALD $\mathrm{SiN}_{\mathrm{x}}$ films deposited using higher frequency showed less $\mathrm{Si}-\mathrm{H}$ and $\mathrm{N}-\mathrm{H}$ bonding compared to those using lower frequency.

\section{3) Process temperature}

PEALD methods can lower the deposition temperature compared to other deposition techniques. However, a considerably lower process temperature is still required for $\operatorname{SiN}_{\mathrm{x}}$ PEALD for various applications of $\mathrm{SiN}_{\mathrm{x}}$ films. For example, in the case of polymer or flexible substrates, very low process temperatures are required. The effect of the substrate temperature on the surface reaction mechanism 
in $\mathrm{SiN}_{\mathrm{x}}$ PEALD systems has been studied. Results showed that the PEALD process could lower the process temperature compared to other deposition techniques (LPCVD and ALD, etc.). However, the quality of $\mathrm{SiN}_{\mathrm{x}}$ thin films is still temperature dependent.

Park et al. investigated the effect of process temperature on step coverage and wet etch rate [37]. They deposited $\mathrm{SiN}_{\mathrm{x}}$ films on trench patterned wafers (aspect ratio (AR) of 5.5) using 1,3-di-isopropylamino2,4-dimethylcyclosilazane (CSN-2) precursor and $\mathrm{N}_{2}$ plasma $(27.12$ $\mathrm{MHz}$ ) at temperatures between 250 and $500{ }^{\circ} \mathrm{C}$. As shown in Fig. 5, $\mathrm{SiN}_{\mathrm{x}}$ thin films grown at $500{ }^{\circ} \mathrm{C}$ showed a high step coverage of $98 \%$ at the center of the trench. With increasing temperature, the step coverage of the middle and bottom side walls showed substantial enhancement in conformality. In addition, the wet etch rate of a silicon nitride film in a diluted HF solution (300:1 diluted HF solution) decreased with an increasing process temperature as shown in Fig. 6. Differences in the wet etch rates of the bottom and lower sidewalls also decreased for films deposited at $500{ }^{\circ} \mathrm{C}$. These results indicate that a higher process temperature offers more reactions between $\mathrm{N}$ radicals of the plasma and the precursor ligands on the surface. At a high process temperature, $\mathrm{N}$ radicals can reach the lower sidewall of the trench and effectively remove ligands from the surface, which results in excellent step coverage and wet etch rate.

Similarly, Jang et al. studied the temperature dependency of $\operatorname{SiN}_{\mathrm{x}}$ thin film properties such as surface roughness and refractive index [27]. Their results revealed that $\mathrm{SiN}_{\mathrm{x}}$ thin films deposited at lower temperatures showed lower defect density caused by high hydrogen content.

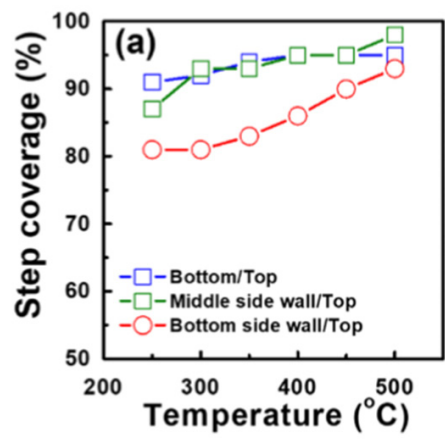

(b)

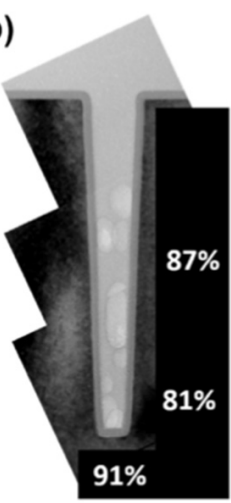

(c)

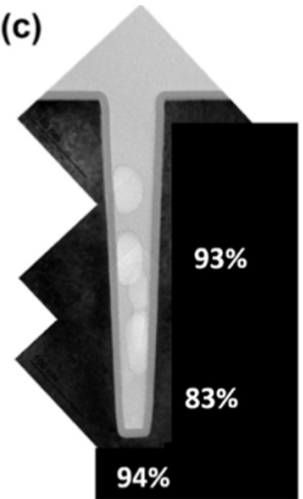

(d)

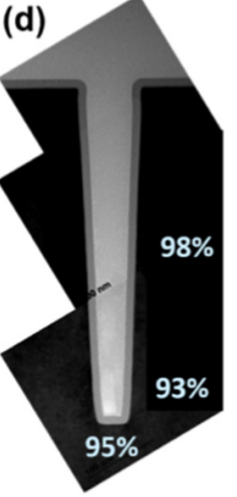

Figure 5. (Color online) (a) Step coverage of PEALD $\mathrm{SiN}_{x}$ thin film deposited by PEALD at various process temperatures. Cross-sectional TEM images of $\mathrm{SiN}_{\mathrm{x}}$ thin films deposited by PEALD consisting of CSN-2 exposure and $\mathrm{N}_{2}$ plasma at (b) 250 , (c) 350 , and (d) $500{ }^{\circ} \mathrm{C}$. Reproduced with permission from [37], Copyright 2018, American Chemical Society.
High defect density is the common reason for hysteresis in a capacitance-voltage $(\mathrm{C}-\mathrm{V})$ curve. Therefore, as shown in Fig. 7, the $\mathrm{SiN}_{\mathrm{x}}$ thin film deposited at $250{ }^{\circ} \mathrm{C}$ showed a considerably lower hysteresis curve. Although lower hysteresis was observed at lower PEALD temperature because of the high hydrogen content, crystallographic defects were found to be higher at lower deposition temperatures. In addition, hydrogen could be removed during processes such as annealing. Therefore, the deposition of $\mathrm{SiN}_{\mathrm{x}}$ at the lower PEALD temperature tends to cause more defect formation in the film.

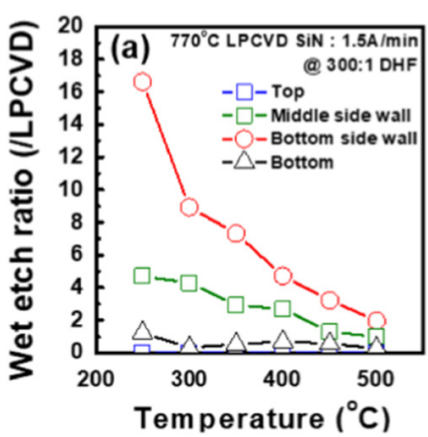

(b)

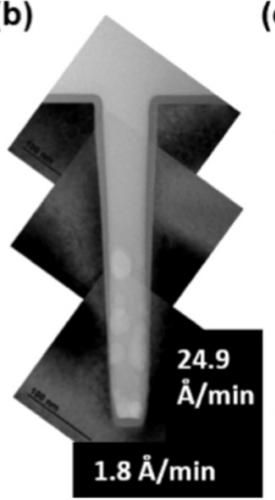

(c)

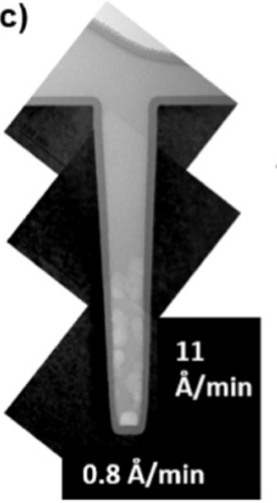

(d)

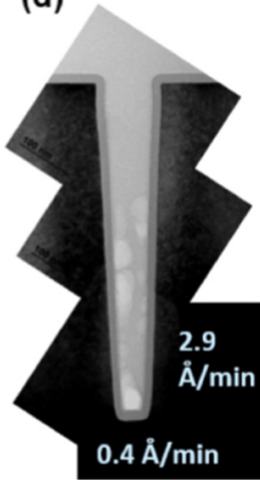

Figure 6. (Color online) (a) Wet etch rate of PEALD $\mathrm{SiN}_{\mathrm{x}}$ depending on process temperature. Cross-sectional TEM images of $\mathrm{SiN}_{x}$ films deposited by PEALD consisting of CSN-2 exposure and $\mathrm{N}_{2}$ plasma at (b) 250 , (c) 350 , and (d) $500{ }^{\circ} \mathrm{C}$ after wet etch in a 300:1 diluted HF solution. Reproduced with permission from [37], Copyright 2018, American Chemical Society.

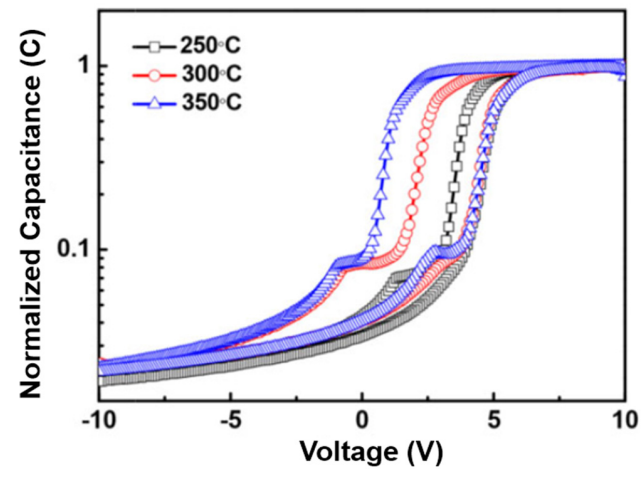

Figure 7. (Color online) $\mathrm{C}-\mathrm{V}$ curves of $\mathrm{SiN}_{\mathrm{x}}$ films deposited by PEALD as a function of process temperature. Reproduced with permission from [27], Copyright 2014, John Wiley and Sons. 


\section{Properties of $\operatorname{SiN}_{x}$}

In this section, we discuss common properties of $\mathrm{SiN}_{\mathrm{x}}$ thin films. These properties are important for applications of the film.

\section{1) Step coverage}

When the feature size of a semiconductor device decreases, high conformality on high aspect ratio structures is a critical requirement. Studies on $\mathrm{SiN}_{\mathrm{x}}$ PEALD focusing on the conformality of the film have been reported. For example, Faraz et al. deposited a $\operatorname{SiN}_{\mathrm{x}}$ layer on trench-patterned wafers with an aspect ratio of 4.5 using a PEALD method [33]. Films were deposited by alternating the exposures of $\mathrm{di}\left(\mathrm{sec}\right.$-butylamino)silane (DSBAS) precursor and $\mathrm{N}_{2}$ plasma (13.56 $\mathrm{MHz}$ ) at $500{ }^{\circ} \mathrm{C}$. The step coverage of $\mathrm{SiN}_{\mathrm{x}}$ film was examined. As shown in Fig. 8, a bottom coverage of $69 \%$ and sidewall coverage of $50 \%$ were observed using PEALD. The step coverage was not as good as that in ALD processes. However, several reports on $\mathrm{SiN}_{\mathrm{x}}$ thin films deposited by the PEALD method showed a good step coverage of above $90 \%$.

Ovanesyan et al. [36] reported $\mathrm{SiN}_{\mathrm{x}}$ thin films with $\sim 95 \%$ conformality on patterned structures (aspect ratio of $\sim 5$ ). Figure 9 is a TEM image for a $\sim 25-\mathrm{nm}$-thick $\mathrm{SiN}_{\mathrm{x}}$ thin film deposited from $\mathrm{Si}_{2} \mathrm{Cl}_{6}$,

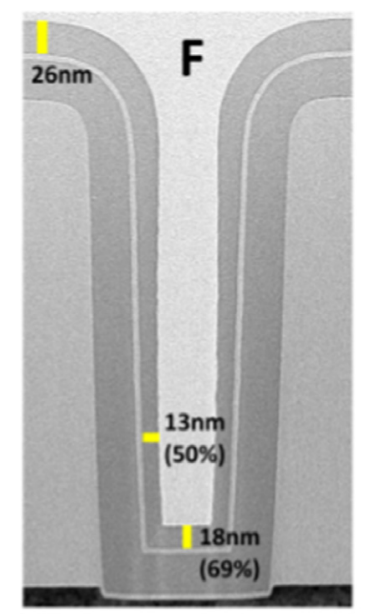

Figure 8. (Color online) Cross-sectional TEM image of $\mathrm{SiN}_{\mathrm{x}}$ thin film deposited on a high aspect ratio structure (AR $=4.5: 1)$ by PEALD using DSBAS and $\mathrm{N}_{2}$ plasma. Reproduced with permission from [33], Copyright 2017, American Chemical Society.

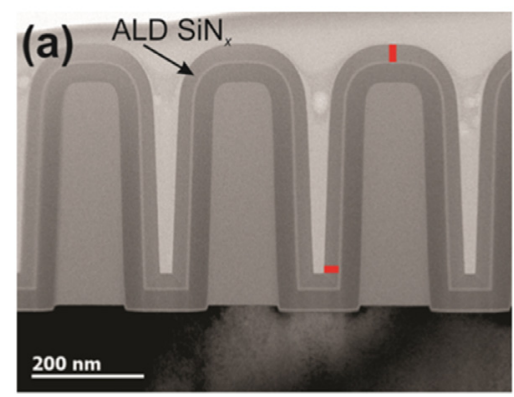

Figure 9. (Color online) Cross-sectional TEM image of post wet-etch $\mathrm{SiN}_{\mathrm{x}}$ deposited by a three-step PEALD process using $\mathrm{Si}_{2} \mathrm{Cl}_{6}, \mathrm{CH}_{3} \mathrm{NH}_{2}$, and $\mathrm{N}_{2}$ plasma at $400{ }^{\circ} \mathrm{C}$. Reproduced with permission from [36], Copyright 2018, American Chemical Society.
$\mathrm{CH}_{3} \mathrm{NH}_{2}$, and $\mathrm{N}_{2}$ plasma at $400{ }^{\circ} \mathrm{C}$. In this case, Ovanesyan et al. [36] suggested a novel three-step PEALD process. By adding a $\mathrm{CH}_{3} \mathrm{NH}_{2}$ exposure step in the PEALD cycle, conformality and growth rate per cycle (GPC) were increased compared to those with the PEALD method using aminosilanes and $\mathrm{N}_{2}$ plasma. Park et al. [37] also reported that $\mathrm{SiN}_{\mathrm{x}}$ thin films deposited by PEALD at $500{ }^{\circ} \mathrm{C}$ showed a high conformality of $\sim 95 \%$ on patterned wafers of AR 5.5. Thus, PEALD methods can be used to deposit $\mathrm{SiN}_{\mathrm{x}}$ thin films with high conformality on trench structures. However, to achieve higher conformality on a high aspect ratio structure $(\mathrm{AR}>6)$ with low process temperature, various attempts such as using a novel Si precursor or additional steps in PEALD process are required.

\section{2) Wet etch rate}

The wet etch rate is highly correlated with the integrity and density of the film. Kim et al. [5] demonstrated the relationship between film density and wet etch rate and suggested a $\mathrm{SiN}_{\mathrm{x}}$ etching mechanism. They investigated the effects of plasma gas composition and process temperature on wet etch rates of $\mathrm{SiN}_{\mathrm{x}}$ deposited by PEALD. The $\mathrm{SiN}_{\mathrm{x}}$ thin films deposited using hexachlorodisilane (HCDS) precursor and $\mathrm{Ar} / \mathrm{NH}_{3}$ plasma at $300{ }^{\circ} \mathrm{C}$ showed a wet etch rate of 1.2 $\mathrm{nm} / \mathrm{min}$ in a $500: 1 \mathrm{HF}$ solution. By comparing the wet etch rates of $\mathrm{SiN}_{\mathrm{x}}$ deposited at various conditions, Kim et al. [5] found that the densification of the $\mathrm{SiN}_{\mathrm{x}}$ thin film is caused by increased $\mathrm{Si}-\mathrm{N}$ bonds, which eliminate hydrogen and result in low wet etch rates.

In another study, Knoops et al. [29] deposited $\mathrm{SiN}_{\mathrm{x}}$ thin films on planar substrates using bis(tertiary-butyl-amino)silane (BTBAS) and $\mathrm{N}_{2}$ plasma at $400{ }^{\circ} \mathrm{C}$, and they investigated the wet etch rate of the films before and after a dip in a 7:1 HF solution $\left(\mathrm{H}_{2} \mathrm{O}: \mathrm{HF}=7: 1\right)$. A low wet etch rate $(\sim 1 \mathrm{~nm} / \mathrm{min})$ was obtained because of the low hydrogen concentration in the films. This result is comparable to the wet etch rate of the $\mathrm{SiN}_{\mathrm{x}}$ thin film deposited by chemical vapor deposition (CVD) at high temperature.

Besides studies on the wet etch rate of $\mathrm{SiN}_{\mathrm{x}}$ thin films on planar surfaces, the wet etch rate has also been studied for high aspect ratio structures. However, most studies showed different wet etch rates for the sidewall, bottom, and top surface of 3D trench patterns [36]. The poor wet etch rate at the bottom sidewall is problematic in silicon nitride PEALD processes.

\section{Concluding remarks}

This brief review examined not only the deposition of $\mathrm{SiN}_{\mathrm{x}}$ thin films using the PEALD process, but also summarized the characteristics of $\mathrm{SiN}_{\mathrm{x}}$ thin films. Compared to other deposition methods, the PEALD process provides atomic scale thickness control and excellent conformality with a lower process temperature. Various $\mathrm{SiN}_{\mathrm{x}}$ PEALD processes have been studied, and some results have shown excellent film properties such as good step coverage and low wet etch rate. However, for device applications, several issues need to be solved. To address these issues, the effect of each PEALD process parameter (temperature, plasma power, exposure time, and gas composition) on the film growth mechanism needs to be understood in detail. Further, new plasma sources and precursors that can deposit highly conformal and dense thin films at low process temperatures for a variety of state-of-the-art devices, which require $\mathrm{SiN}_{\mathrm{x}}$ thin films, must be developed. Further studies on the deposition mechanism are required to enhance the quality of the deposited $\mathrm{SiN}_{\mathrm{x}}$ thin films. 


\section{References}

[1] F. Koehler, D. H. Triyoso, I. Hussain, B. Antonioli, and K. Hempel, Phys. Status Solidi C 11, 73 (2014).

[2] D. H. Triyoso, V. Jaschke, J. Shu, S. Mutas, K. Hempel, J. K. Schaeffer, and M. Lenski, IEEE International Conference on IC Design \& Technology (Austin, TX, USA, May 30-June 1, 2012), pp. $1-4$.

[3] D. H. Triyoso, K. Hempel, S. Ohsiek, V. Jaschke, J. Shu, S. Mutas, K. Dittmar, J. Schaeffer, D. Utess, and M. Lenski, J. Solid State Sci. Technol. 2, N222 (2013).

[4] E. Vianello, F. Driussi, L. Perniola, G. Molas, J. P. Colonna, B. De Salvo, and L. Selmi, IEEE Trans. Electron Devices 58, 2483 (2011).

[5] H. S. Kim, X. Meng, S. J. Kim, A. T. Lucero, L. Cheng, Y. C. Byun, J. S. Lee, S. M. Hwang, A. L. N. Kondusamy, R. M. Wallace, G. Goodman, A. S. Wan, M. Telgenhoff, B. K. Hwang, and J. Kim, ACS Appl. Mater. Interfaces 10, 44825 (2018).

[6] A. Kaneko, A. Yagishita, K. Yahashi, T. Kubota, M. Omura, K. Matsuo, I. Mizushima, K. Okano, H. Kawasaki, S. Inaba, T. Izumida, T. Kanemura, N. Aoki, K. Ishimaru, H. Ishiuchi, K. Suguro, K. Eguchi, and Y. Tsunashima, IEEE International Electron Devices Meeting, IEDM Technical Digest (Washington, DC, USA, December 5, 2005), pp. 844-847.

[7] D. S. Wuu, W. C. Lo, C. C. Chiang, H. B. Lin, L. S. Chang, R. H. Horng, C. L. Huang, and Y. J. Gao, Surf. Coat. Technol. 198, 114 (2005).

[8] F. J. van Assche, S. Unnikrishnan, J. J. Michels, A. M. van Mol, P. van de Weijer, M. C. van de Sanden, and M. Creatore, Thin Solid Films 558, 54 (2014).

[9] C. C. Chiang, D. S. Wuu, H. B. Lin, Y. P. Chen, T. N. Chen, Y. C. Lin, C. C. Wu, W. C. Chen, T. H. Jaw, and R. H. Horng, Surf. Coat. Technol. 200, 5843 (2006).

[10] S. Zhang, W. Xue, and Z. Yu, Thin Solid Films 580, 101 (2015).

[11] W. M. Arnoldbik, C. H. M. Maree, A. J. H. Maas, M. J. van den Boogaard, F. H. P. M. Habraken, and A. E. T. Kuiper, Phys. Rev. B: Condens. Matter Mater. Phys. 48, 5444 (1993).

[12] B. C. Joshi, G. Eranna, D. P. Runthala, B. B. Dixit, O. P. Wadhawan, and P. D. Vyas, Indian J. Eng. Mater. Sci. 7, 303 (2000).

[13] W. Huang, X. Wang, M. Sheng, L. Xu, F. Stubhan, L. Luo, T. Feng, X. Wang, F. Zhang, and S. Zou, Mater. Sci. Eng. B, 98, 248 (2003).

[14] K. F. Roenigk and K. F. Jensen, J. Electrochem. Soc. 134, 1777 (1987).

[15] S. W. King, J. Vac. Sci. Technol. A 29, 041501 (2011).

[16] B. Karunagaran, J. P. Jeong, S. Nagarajan, S. J. Chung, and E. K. Suh, J. Korean Phys. Soc. 48, 1250 (2006).

[17] G. Beshkov, S. Lei, V. Lazarova, N. Nedev, and S. S. Georgiev, Vacuum 69, 301 (2002).

[18] X. Liu, X. Pu, H. Li, F. Qiu, and L. Huang, Mater. Lett. 59, 11 (2005).

[19] A. Nakajima, T. Yoshimoto, T. Kidera, and S. Yokoyama, Appl. Phys. Lett. 79, 665 (2001).
[20] L. L. Yusup, J. M. Park, Y. H. Noh, S. J. Kim, W. J. Lee, S. Park, and Y. K. Kwon, RSC Adv. 6, 68515 (2016).

[21] X. Meng, Y. C. Byun, H. Kim, J. Lee, A. Lucero, L. Cheng, and J. Kim, Materials 9, 1007 (2016).

[22] J. W. Klaus, A. W. Ott, A. C. Dillon, and S. M. George, Surf. Sci. 418, L14 (1998).

[23] W. J. Lee, J. H. Lee, C. O. Park, Y. S. Lee, S. J. Shin, and S. K. Rha, J. Korean Phys. Soc. 45, 1352 (2004).

[24] A. Nakajima, Q. D. M. Khosru, T. Yoshimoto, T. Kidera, and S. Yokoyama, Appl. Phys. Lett. 80, 1252 (2002).

[25] W. J. Lee, U. J. Kim, C. H. Han, M. H. Chun, S. K. Rha, and Y. S. Lee, J. Korean Phys. Soc. 47, S598 (2005).

[26] K. Park, W. D. Yun, B. J. Choi, H. Do Kim, W. J. Lee, S. K. Rha, and C. O. Park, Thin Solid Films 517, 3975 (2009).

[27] W. Jang, H. Jeon, C. Kang, H. Song, J. Park, H. Kim, H. Seo, M. Leskela, and H. Jeon, Phys. Status Solidi A 211, 2166 (2014).

[28] R. A. Ovanesyan, D. M. Hausmann, and S. Agarwal, ACS Appl. Mater. Interfaces 7, 10806 (2015).

[29] H. C. Knoops, E. M. Braeken, K. de Peuter, S. E. Potts, S. Haukka, V. Pore, and W. M. Kessels, ACS Appl. Mater. Interfaces 7, 19857 (2015).

[30] J. Provine, P. Schindler, Y. Kim, S. P. Walch, H. J. Kim, K. H. Kim, and F. B. Prinz, AIP Adv. 6, 065012 (2016).

[31] J. M. Park, S. J. Jang, L. L. Yusup, W. J. Lee, and S. I. Lee, ACS Appl. Mater. Interfaces 8, 20865 (2016).

[32] S. Weeks, G. Nowling, N. Fuchigami, M. Bowes, and K. Littau, J. Vac. Sci. Technol. A 34, 01A140 (2016).

[33] T. Faraz, M. van Drunen, H. C. Knoops, A. Mallikarjunan, I. Buchanan, D. M. Hausmann, J. Henri, and W. M. Kessels, ACS Appl. Mater. Interfaces 9, 1858 (2017).

[34] J. H. Han, J. M. Choi, S. H. Lee, W. Jeon, and J. S. Park, Ceram. Int. 44, 20890 (2018).

[35] X. Meng, H. S. Kim, A. T. Lucero, S. M. Hwang, J. S. Lee, Y. C. Byun, J. Kim, B. K. Hwang, X. Zhou, J. Young, and M. Telgenhoff, ACS Appl. Mater. Interfaces 10, 14116 (2018).

[36] R. A. Ovanesyan, D. M. Hausmann, and S. Agarwal, ACS Appl. Mater. Interfaces 10, 19153 (2018).

[37] J. M. Park, S. J. Jang, S. I. Lee, and W. J. Lee, ACS Appl. Mater. Interfaces 10, 9155 (2018).

[38] R. H. Bosch, L. E. Cornelissen, H. C. Knoops, and W. M. Kessels, Chem. Mater. 28, 5864 (2016).

[39] A. M. Andringa, A. Perrotta, K. de Peuter, H. C. Knoops, W. M. Kessels, and M. Creatore, Appl. Mater. Interfaces 7, 22525 (2015).

[40] P. C. Jhang, C. P. Lu, J. Y. Shieh, L. W. Yang, T. Yang, K. C. Chen, and C. Y. Lu, Solid-State Electron. 133, 10 (2017).

[41] H. Goto, K. Shibahara, and S. Yokoyama, Appl. Phys. Lett. 68, 3257 (1996).

[42] S. Yokoyama, N. Ikeda, K. Kajikawa, and Y. Nakashima, Appl. Surf. Sci. 130, 352 (1998).

[43] S. Riedel, J. Sundqvist, and T. Gumprecht, Thin Solid Films 577, 114 (2015). 